\title{
HUBUNGAN PARTISIPASI DALAM PROGRAM PEMBERDAYAAN UMKM DENGAN TINGKAT KESEJAHTERAAN PESERTA
}

\section{Relations of Participation in the UMKM Empowerment Program with Participants Welfare}

\author{
Aldina Hapsari ${ }^{1)}$ dan Rilus A Kinseng ${ }^{1)}$ \\ ${ }^{1)}$ Departemen Sains Komunikasi dan Pengembangan Masyarakat, Fakultas Ekologi Manusia, \\ Institut Pertanian Bogor, Darmaga Bogor 16680, Indonesia \\ Email: hapsari.aldinahap@gmail.com; rilus@apps.ipb.ac.id
}

\begin{abstract}
Empowerment is one of way to increase community's roles in build community welfare. The success of an empowerment processes cannot be released from the fact that participation of the residents, either as the unity of the system and as an individual that is part a very integrated, and it was very important in the process of dynamic of development. One of the programs the empowerment undertaken by the government at this time is empowerment micro and small entrepreneus who below Pusat Layanan Usaha Terpadu (PLUT).The purpose of this paper is to identify relations umkm participation in the program empowerment an welfare participants. This research uses a quantitative approach with survey methods are supported by qualitative data in the form of in-depth interviews, observation, as well as the analysis of references such as theses, scientific journals, textbooks, articles, monograph, as well as reports on other research results. The result of this research is there is no relationship between the level of participation with community's welafare.
\end{abstract}

Keywords: welfare, participation, empowerment, UMKM

\begin{abstract}
ABSTRAK
Pemberdayaan merupakan salah satu cara meningkatkan peran masyarakat dalam memajukan kesejahteraan masyarakat. Keberhasilan suatu proses pemberdayaan tidak dapat dilepaskan dari adanya partisipasi anggota masyarakatnya, baik sebagai kesatuan sistem maupun sebagai individu yang merupakan bagian yang sangat terintegrasi, dan sangat penting dalam proses dinamika pembangunan. Salah satu program pemberdayaan yang dilakukan oleh pemerintah saat ini adalah pemberdayaan UMKM yang berada dibawah Pusat Layanan Usaha Terpadu (PLUT). Tujuan dari tulisan ini adalah untuk menganalisis hubungan partisipasi UMKM dalam program pemberdayaan dan tingkat kesejahteraan peserta. Penelitian ini menggunakan pendekatan kuantitatif dengan metode survey didukung dengan data kualitatif berupa wawancara mendalam, observasi, serta analisis bahan pustaka seperti skripsi, jurnal ilmiah, buku teks, artikel, monograph, serta laporan hasil penelitian lainnya. Hasil dari penelitian ini adalah tidak terdapat hubungan antara tingkat partisipasi dalam program pemberdayaan UMKM dengan tingkat kesejahteraan peserta.
\end{abstract}

Kata Kunci: kesejahteraan, partisipasi, pemberdayaan, UMKM

\section{PENDAHULUAN}

Indonesia merupakan negara agraris karena sebagian besar penduduknya bermatapencaharian di sektor pertanian. Namun, saat ini jumlah lahan pertanian semakin sedikit. Menurut data Badan Pusat Statistik (BPS) (2014), menunjukkan di Pulau Jawa setiap tahun telah terjadi alih fungsi lahan pertanian seluas 27.000 hektar. BPS merilis hasil Sensus Pertanian 2013 yaitu terjadinya penurunan rumah tangga petani dari 31,17 juta rumah tangga pada tahun 2003 menjadi 26,13 juta rumah tangga pada tahun 2013. Salah satu penyebab penurunan tersebut adalah era globalisasi yang menyebabkan terjadinya perubahan struktur ekonomi di 
Indonesia. Era globaliasi yang ditandai dengan masuknya teknologi ke ranah ekonomi mengakibatkan persaingan antara sektor industri dengan sektor pertanian. Perkembangan sektor industri tidak hanya terjadi di wilayah perkotaan.

Perkembangan bidang industri di pedesaan menyebabkan terjadinya pergeseran kesempatan kerja dari pertanian ke non-pertanian. Semakin sempitnya lahan pertanian serta rendahnya keuntungan yang diberikan dari bekerja di bidang pertanian memaksa sebagian besar penduduk di pedesaan beralih haluan mencari pekerjaan di bidang non-pertanian. Sektor industri menjadi penting keberadaanya di tengah-tengah menurunnya pendapatan di bidang pertanian. Berdasarkan survey BPS dari tahun 2004-2010, sektor industri masih menjadi penyumbang terbesar Produk Domestik Bruto (PDB) dan penyedia barang ekspor bagi perdagangan Internasional terutama industri pengolahan bukan migas. Hal ini menunjukkan pentingnya peranan sektor industri yang pada tahun 2009 tecatat memberikan kontribusi terbesar $26,4 \%$ dalam perekonomian Indonesia.

Keberadaan UMKM yang dominan sebagai pelaku ekonomi nasional juga merupakan pengerak dalam pembangunan ekonomi rakyat, khususnya dalam rangka perluasan kesempatan berusaha bagi wirausaha baru dan merupakan sektor ekonomi terbesar dalam penyerapan tenaga kerja serta memberikan sumbangsi dalam menekan angka pengangguran. Salah satu cara meningkatkan peran masyarakat dalam memajukan kesejahteraan antara lain meningkatkan pemberdayaan UMKM. Pemberdayaan adalah suatu kegiatan yang berkesinambungan, dinamis, dan secara sinergis mendorong keterlibatan semua potensi (Suhendra 2006) dan yang dimaksud meningkatkan pemberdayaan UMKM sesuai dengan UU No.20 Tahun 2008 yaitu pemerintah memberikan ijin usaha bagi para pelaku usaha untuk menjalankan suatu kegiatan usaha tertentu; pengembangan usaha melalui pemberian fasilitas, bimbingan, pendampingan; bantuan untuk menumbuhkan dan meningkatkan kemampuan dan daya saing usaha; adanya koordinasi dan pengendalian dari pemerintah.
Keberhasilan suatu proses pembangunan tidak dapat dilepaskan dari adanya partisipasi anggota masyarakatnya, baik sebagai kesatuan sistem maupun sebagai individu yang merupakan bagian yang sangat terintegrasi, dan sangat penting dalam proses dinamika pembangunan. Secara prinsip pembangunan ditunjukkan guna mewujudkan masyarakat yang sejahtera. Tingkat partisipasi secara ideal tidak hanya saat pelaksanaan, akan tetapi pada perencanaan, pemanfaatan hasil, dan evaluasi. Keikutsertaan masyarakat dalam setiap tahapan tersebut dapat menumbuhkan rasa memiliki ("sense of ownership" atau "sense of belonging") terhadap sarana dan prasaran yang dibangun atau dibentuk sehingga akan menghasilkan pembangunan yang berkelanjutan (Sudirja 2007). Partisipasi dalam setiap tahapan tersebut pun bertujuan agar masyarakat dapat memiliki keterampilan untuk menggali kebutuhan, merencanakan program, serta memperbaiki kekurangan-kekurangan yang ada pada program.

Menurut Pangestu (1995) faktor internal yang mencakup karakteristik individu dapat mempengaruhi tingkat partisipasi individu dalam sebuah kegiatan sosial, faktor tersebut adalah tingkat umur, tingkat pendidikan, tingkat pendapatan, dan lama tinggal di suatu daerah atau lingkungan sosial. Keempat karakteristik tersebut diduga memiliki peran bagi individu dalam menentukan pandangan, pilihan, sikap, serta tindakan untuk ikut atau tidak dalam sebuah kegiatan sosial. Menarik kemudian untuk dilihat, bagaimana hubungan karakteristik individu dengan tingkat partisipasi responden program pemberdayaan UMKM?

Tingkat partisipasi masyarakat dalam program pemberdayaan dapat diukur dengan tingkatan partisipasi Cohen dan Uphoff (1979) dan tingkat partisipasi Arnstein (1969). Cohen dan Uphoff (1979) membagi partisipasi ke beberapa tahapan, yaitu sebagai berikut tahap perencanaan, tahap pelaksanaan, tahap menikmati hasil, tahap evaluasi. Bagaimana hubungan tingkat partisipasi peserta pemberdayaan UMKM dengan tingkat kesejahteraan peserta? 


\section{PENDEKATAN TEORITIS}

\section{Pemberdayaan}

Secara etimologis pemberdayaan berasal dari kata dasar "daya" yang berarti kekuatan atau kemampuan (Sulistiyani 2004). Bertolak dari pengertian tersebut, maka pemberdayaan dimaknai sebagai proses untuk memperoleh daya, kekuatan atau kemampuan, dan atau pemberian daya, kekuatan atau kemampuan dari pihak yang memiliki daya kepada pihak yang kurang atau belum berdaya. Friedman (1992) mendefinisikan pemberdayaan sebagai pendekatan alternatif untuk membangun inisiatif masyarakat, dimana negara berperan dalam menciptakan kondisi yang memungkinkan, memfasilitasi, dan mendukung. Sedangkan menurut Pranarka dan Moejato (1996) konsep pemberdayaan atau empowerment pada dasarnya adalah upaya menjadikan suasana yang adil dan beradap dalam kehidupan masyarakat yang diberdayakan.

Pemberdayaan pada dasarnya merupakan suatu proses yang dijalankan dengan kesadaran dan partisipasi penuh dari para pihak untuk meningkatkan kapasitas dan kapabilitas masyarakat sebagai sumber daya pembangunan agar mampu mengenali permasalahan yang dihadapi dalam mengembangkan dan menolong diri menuju keadaan yang lebih baik, mampu menggali dan kelompoknya, serta mampu mengeksistensikan diri secara jelas dengan mendapat manfaat darinya. Pemberdayaan adalah sebuah "proses menjadi", bukan "proses instan". Sebagai proses, pemberdayaan mempunyai tiga tahapan yaitu penyadaran, pengkapasitasan, dan pendayaan.

Konsep pemberdayaan yang dimaksud dalam penelitian ini adalah pemberdayaan yang dilakukan terhadap UMKM. Menurut undangundang Nomor 20 Tahun 2008 tentang Usaha Mikro, Kecil dan Menengah, mendefinisikan pemberdayaan sebagai upaya yang dilakukan pemerintah, pemerintah daerah, dunia usaha, dan masyarakat secara sinergis dalam bentuk penumbuhan iklim dan pengembangan usaha terhadap UMKM, sehingga mampu tumbuh dan berkembangan menjadi usaha yang tangguh dan mandiri. Dari berbagai pandangan mengenai konsep pemberdayaan, maka dapat disimpulkan, bahwa pemberdayaan UMKM merupakan salah satu alternatif yang dipilih pemerintah dalam upaya mengurangi pengangguran, mengentas kemiskinan dan pemerataan pendapatan. Pemberdayaan UMKM dilakukan dengan menumbuhkan dan mengembangkan sektor usaha kecil.

\section{Partisipasi}

Partisipasi menurut Sajogyo (1998) adalah peluang untuk ikut menentukan kebijaksanaan pembangunan serta peluang ikut menilai hasil pembangunan. Tilaar (2009) mengungkapkan partisipasi adalah sebagai wujud dari keinginan untuk mengembangkan demokrasi melalui proses desentralisasi dimana diupayakan antara lain perlunya perencanaan dari bawah (bottom-up) dengan mengikutsertakan masyarakat dalam proses perencanaan dan pembangunan masyarakatnya. Sedangkan, Nasdian (2006) mendefinisikan pasrtisipasi sebagi proses aktif, inisiatif diambil oleh warga komunitas sendiri, dibimbing oleh cara berfikir mereka sendiri, dengan menggunakan sarana dan proses (lembaga dan mekanisme) dimana mereka dapat menegaskan kontrol secara efektif.

Menurut Rosyida dan Nasdian (2011), tingkat partisipasi masyarakat dalam program pemberdayaan dapat diukur dengan tingkatan partisipasi Cohen dan Uphoff (1979) dan tingkat partisipasi Arnstein (1969). Cohen dan Uphoff (1979) membagi partisipasi ke beberapa tahapan, yaitu sebagai berikut:

1. Tahap pengambilan keputusan atau tahap perencanaan, yang diwujudkan dengan keikutsertaan masyarakat dalam rapat-rapat. Tahap pengambilan keputusan yang dimaksud disini yaitu pada perencanaan dan pelaksanaan suatu program. Tahap pelaksanaan yang merupakan tahap terpenting dalam pembangunan, sebab inti dari pembangunan adalah pelaksanaanya. Wujud nyata partisipasi pada tahap ini digolongkan menjadi tiga, yaitu partisipasi dalam bentuk sumbangan pemikiran, bentuk sumbangan materi, dan bentuk tindakan sebagai anggota proyek.

2. Tahap menikmati hasil, yang dapat dijadikan indikator keberhasilan partisipasi masyarakat 
pada tahap perencanaan dan pelaksanaan proyek. Selain itu, dengan melihat posisi masyarakat sebagai subjek pembangunan, maka semakin besar manfaat proyek dirasakan, berarti proyek tersebut berhasil mengenai sasaran.

3. Tahap evaluasi, dianggap penting sebab partisipasi masyarakat pada tahap ini merupakan umpan balik yang dapat memberi masukan demi perbaikan pelaksanaan proyek selanjutnya.

\section{Usaha Mikro, Kecil, dan Menengah (UMKM)}

Menurut UU No. 20 Tahun 2008 Pasal 3 tentang Usaha Mikro, Kecil dan Menengah, maka yang dimaksud dengan Usaha Mikro, Kecil dan Menengah yaitu:

1. Usaha Mikro adalah usaha produktif milik orang perorangan dan atau badan usaha perorangan yang memenuhi kriteria usaha mikro sebagaimana diatur dalam Undangundang ini.

2. Usaha Kecil adalah usaha ekonomi produktif yang berdiri sendiri, yang dilakukan oleh orang perorangan atau badan usaha yang bukan merupakan anak perusahaan atau bukan cabang perusahaan yang dimiliki, dikuasai atau menjadi bagian baik langsung maupun tidak langsung dari usaha menengah atau usaha besar yang memenuhi kriteria usaha kecil sebagaimana yang dimaksud dalam UU ini.

3. Usaha Menengah adalah usaha ekonomi produktif yang berdiri sendiri, yang dilakukan oleh orang perorangan atau badan usaha yang bukan merupakan anak perusahaan atau cabang perusahaan yang dimiliki, dikuasai atau menjadi bagian baik langsung maupun tidak langsung dengan usaha kecil atau usaha Besar dengan jumlah kekayaan bersih atau hasil penjualan tahunan sebagaimana diatur dalam UU ini.

Pemberdayaan dan pengembangan Usaha Mikro, Kecil dan Menengah (UMKM) merupakan upaya yang ditempuh pemerintah untuk mengatasi masalah pengangguran dan kemiskinan. Pada Bab II pasal 5 UU No 20 tahun 2008 tentang Usaha Mikro, Kecil dan Menengah (UMKM).
Tujuan pemberdayaan Usaha Mikro, Kecil dan Menengah:

1. Mewujudkan struktur perekonomian nasional yang seimbang, berkembang dan berkeadilan.

2. Menumbuhkan dan mengembangkan kemampuan Usah Mikro, Kecil dan Menengah menjadi usaha yang tangguh dan mandiri.

3. Meningkatkan peran Usaha Mikro, Kecil dan Menengah dalam pembangunan daerah, penciptaan lapangan kerja, pemerataan pendapatan, pertumbuhan ekonomi dan pengentasan rakyat dari kemiskinan.

\section{Kesejahteraan}

Menurut Undang-undang No 11 Tahun 2009, tentang Kesejahteraan Masyarakat, kesejahteraan masyarakat adalah kondisi terpenuhinya kebutuhan material, spiritual, dan sosial warga negara agar dapat hidup layak dan mampu mengembangkan diri, sehingga dapat melaksanakan fungsi sosialnya. Dari UndangUndang di atas dapat kita cermati bahwa ukuran tingkat kesejahteraan dapat dinilai dari kemampuan seorang individu atau kelompok dalam usaha nya memenuhi kebutuhan material dan spiritual nya. Kebutuhan material dapat kita hubungkan dengan pendapatan yang nanti akan mewujudkan kebutuhan akan pangan, sandang, papan dan kesehatan. Kemudian kebutuhan spiritual kita hubungkan dengan pendidikan, kemudian keamanan dan ketentaraman hidup.

Menurut Mosher (1987), hal yang paling penting dari kesejahteraaan adalah pendapatan, sebab beberapa aspek dari kesejahteraan rumah tangga tergantung pada tingkat pendapatan. Pemenuhan kebutuhan dibatasi oleh pendapatan rumah tangga yang dimiliki, terutama bagi yang berpendapatan rendah. Semakin tinggi pendapatan rumah tangga maka persentase pendapatan untuk pangan akan semakin berkurang. Dengan kata lain, apabila terjadi peningkatan tersebut tidak merubah pola konsumsi maka rumah tangga tersebut sejahtera. Sebaliknya, apabila peningkatan pendapatan rumah tangga dapat merubah pola konsumsi maka rumah tangga tersebut tidak sejahtera. 
Badan Pusat Statistik Indonesia (2000) menerangkan bahwa guna melihat tingkat kesejahteraan rumah tangga suatu wilayah ada beberapa indikator yang dapat dijadikan ukuran, antara lain adalah: (1) Tingkat pendapatan keluarga; (2) Komposisi pengeluaran rumah tangga dengan membandingkan pengeluaran untuk pangan dengan non-pangan; (3) Tingkat pendidikan keluarga; (4) Tingkat kesehatan keluarga; (5) Kondisi perumahan serta fasilitas yang dimiliki dalam rumah tangga.

Informasi mengenai kondisi sosial ekonomi masyarakat yang telah dikumpulkan melalui Susenas, digunakan sebagai dasar untuk memperoleh berbagai indikator pencapaian kesejahteraan rakyat. Indikator tersebut meliputi: angka partisipasi sekolah dan angka melek huruf untuk bidang pendidikan; angka morbiditas, pemanfaatan fasilitas kesehatan, jaminan kesehatan, pemberian ASI pada baduta, dan imunisasi untuk bidang kesehatan, dan penolong persalinan; umur perkawinan pertama, partisipasi $\mathrm{KB}$, dan rata-rata jumlah anak yang dilahirkan untuk bidang fertilitas dan $\mathrm{KB}$; kondisi tempat tinggal, sumber air untuk minum, memasak, mandi dan mencuci untuk bidang perumahan, kepemilikan HP, akses internet dalam pemanfaatan teknologi informasi, serta bantuan/program pemerintah untuk kesejahteraan masyarakat (BPS 2015).

\section{Kerangka Pemikiran}

Tingkat partisipasi peserta program berhubungan dengan karakteristik individu peserta. Indikator karakteristik individu yang diteliti dalam penelitian ini adalah tingkat umur, tingkat pendidikan, dan tingkat pendapatan. Keseluruhan indikator tersebut diduga memiliki hubungan dengan tingkat keaktifan peserta program dalam berpartisipasipada program pemberdayaan UMKM di Kabupaten subang.

Keberhasilan suatu proses pembangunan tidak dapat dilepaskan dari adanya partisipasi anggota masyarakatnya, baik sebagai kesatuan sistem maupun sebagai individu yang merupakan bagian yang sangat terintegrasi, dan sangat penting dalam proses dinamika pembangunan. Secara prinsip pembangunan ditunjukkan guna mewujudkan masyarakat yang sejahtera. Tingkat partisipasi secara ideal tidak hanya saat pelaksanaan, akan tetapi pada perencanaan, pemanfaatan hasil, dan evaluasi. Keikutsertaan masyarakat dalam setiap tahapan tersebut dapat menumbuhkan rasa memiliki ("sense of ownership" atau "sense of belonging") terhadap sarana dan prasaran yang dibangun atau dibentuk sehingga akan menghasilkan pembangunan yang berkelanjutan (Sudirja 2007). Partisipasi dalam setiap tahapan tersebut pun bertujuan agar masyarakat dapat memiliki keterampilan untuk menggali kebutuhan, merencanakan program, serta memperbaiki kekurangan-kekurangan yang ada pada program.

Penelitian tentang partisipasi UMKM dalam program pemberdayaan dan tingkat kesejahteraan ini akan dilakukan dengan meninjau tiga dari empat partisipasi sebagaimana di utarakan Cohen dan Uphoff (1997) bahwa partisipasi terdiri dari tahapan dari tahapan pelaksanaan, menikmati hasil dan evaluasi. Selanjutnya dilakukan analisa untuk melihat sejauh mana tingkat kesejahteraan yang dirasakan peserta setelah mengikuti program pemberdayaan tersebut. Indikator tingkat kesejahteraan dalam penelitian ini terdiri dari pendapatan, kemampuan akses pendidikan, kemampuan akses kesehatan, dan perumahan.

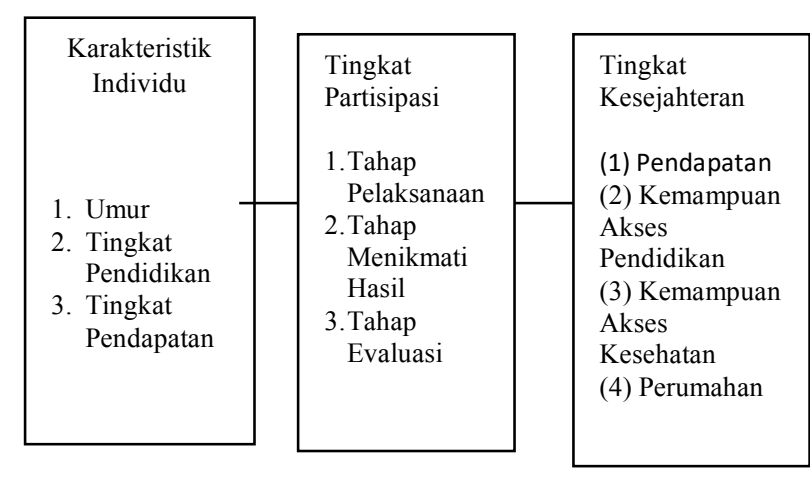

Keterangan: — berhubungan

\section{Hipotesis}

Penelitian ini memiliki dua hipotesis yaitu:

1. Terdapat hubungan antara karakteristik responden dengan tingkat partisipasi responden dalam program pemberdayaan UMKM; 
2. Terdapat hubungan antara tingkat partisipasi dengan tingkat kesejahteraan peseta.

\section{PENDEKATAN LAPANGAN}

Penelitian ini menggunakan pendekatan kuantitatif yang didukung dengan data kualitatif. Pendekatan kuantitatif digunakan untuk menjawab pertanyaan mengenai tingkat partisipasi peserta dalam program pemberdayaan UMKM dan tingkat kesejahteraan peserta. Data kuantitatif diperoleh dengan menggunakan instrumen kuesioner. Data kualitatif digunakan untuk memperkuat data kuantitatif. Pengambilan data kualitatif dilakukan dengan wawancara mendalam (indepth interview) menggunakan panduan pertanyaan kepada para informan.

Penelitian ini ditujukan kepada pemilik UMKM di wilayah Kabupaten Subang, Jawa Barat. Pemilihan lokasi penelitian ini dilakukan secara sengaja (purposive) dengan pertimbangan Kabupaten Subang memiliki banyak UMKM dan adanya PLUT yang memberdayakannya. Penelitian ini dilaksanakan pada bulan Mei 2017.

Pemilihan responden pada penelitian ini dilakukan menggunakan pengambilan sampel acak sederhana (simple random sampling) dengan populasi sebanyak 161 orang. Responden pada penelitian ini diambil sebanyak 45 orang. Responden adalah pemilik UMKM yang terdaftar dalam PLUT. Informan dalam penelitian ini adalah pihak PLUT.

Data yang dibutuhkan dalam penelitian ini meliputi data primer dan data sekunder. Data primer diperoleh secara langsung di lokasi penelitian dengan menggunakan instrumen kuesioner kepada responden, panduan pertanyaan untuk wawancara mendalam kepada responden dan informan, serta observasi mengenai kondisi UMKM di lapang yang berhubungan dengan program pemberdayaan UMKM. Data sekunder berupa data dari Badan Pusat Statistik (BPS), data potensi wilayah, jumlah sebaran pengguna aplikasi Petani, serta data-data terkait yang berasal dari penelitian sebelumnya dalam bentuk jurnal ilmiah maupun skripsi.

Data pada penelitian ini diolah menggunakan aplikasi Microsoft Excel 2016 dan IBM SPSS
Statistics 24.0. Aplikasi Microsoft Excel 2016 digunakan untuk membuat tabel frekuensi, grafik, atau diagram untuk melihat data awal responden untuk masing-masing variabel secara tunggal. Kemudian IBM SPSS Statistics 24.0 digunakan untuk uji statistik yang menggunakan Rank Spearman Correlation untuk menguji ada atau tidaknya hubungan antara dua variabel yang berskala ordinal. Data kualitatif dianalisis melalui tiga tahap, yaitu reduksi data, penyajian data, dan verifikasi data.

\section{HASIL DAN PEMBAHASAN}

\section{Karakteristik Responden}

Usia responden sangat bervariasi. 42,22 persen pengguna berusia 23-35 tahun. Sebaran usia responden didominasi oleh responden pada usia produktif. Responden 62,22 persennya adalah laki-laki dan 37,80 persen sisanya adalah perempuan. Pendidikan terakhir responden ap didominasi lulusan SMA, yaitu sebesar 75,56 persen.

Mayoritas responden, yaitu sebesar 48,89 persen berpendapatan rendah. Responden dengan tingkat pendapatan sedang sebanyak 10 orang atau sebesar $22,22 \%$. Sedangkan responden dengan tingkat pendapatan tinggi hanya tiga orang atau sebesar $6,67 \%$. Rentang tingkat pendapatan responden dari Rp 1.000.000 - Rp 50.000.000.

\section{Partisipasi Tahap Pelaksanaan}

Partsipasi pada tahap pelaksanaan program adalah keikutsertaan dan keaktifan dalam pelaksanaan kegiatan program pengembangan masyarakat yang dilakukan oleh pihak Pusat Layanan Usaha Terpadu (PLUT) Kabupaten Subang. Responden diberikan tujuh pertanyaan berupa pilihan "ya" dan "tidak" yang berkaitan dengan pasrtisipasi responden pada tahap pelaksanaan program, dimana setiap pilihan skor jawaban memiliki bobot yang berbeda. Tingkat partisipasi pada tahap pelaksanaan diukur dengan menjumlahkan skor dari hasil jawaban responden.

Peserta dengan tingkat partisipasi rendah pada tahap pelaksanaan sebanyak 12 orang atau sebesar 26,67\%. Tingkat partisipasi rendah disebabkan para peserta menganggap bahwa 
materi yang disampaikan sudah mereka dapatkan berdasarkan pengalaman mereka dalam berusaha. Pengalaman berusaha yang diperoleh sendiri seperti sistem pengawetan produk, memasarkan produk mereka, membuat desain produk.

Peserta yang kurang aktif atau tingkat partisipasi rendah pada tahap pelaksanaan juga beralasan bahwa mereka tidak ada waktu untuk datang/hadir pada saat program pemberdayaan dilaksanakan. Selain itu juga lokasi tempat tinggal mereka yang jauh dari tempat program pemberdayaan dilaksanakan.

\section{Partisipasi Tahap Menikmati Hasil}

Menikmati hasil merupakan tahapan partisipasi dimana setiap pihak yang terlibat dapat merasakan manfaat dari dilaksanakannya program. Semakin besar manfaat yang dirasakan dari pogram, maka program tersebut telah mengenai sasaran atau tepat sasaran. Tingkat partisipasi pada tahap menikmati hasil diukur dengan menjumlahkan skor.

Peserta dengan tingkat partisipasi rendah pada tahap menikmati hasil berpendapat bahwa kurang mendapat manfaat dari adanya program pemberdayaan UMKM. Hal ini disebabkan harapan dari mereka dengan adanya program ini adalah mereka mendapat modal atau bantuan alat dari PLUT. Namun pada kenyataannya program ini hanya mengadakan pelatihan-pelatihan saja.dari hasil jawaban responden.

\section{Partisipasi Tahap Evaluasi}

Tahap monitoring program adalah keikutsertaan responden dalam memantau kegiatan, yaitu responden menyampaikan secara langsung tentang kendala-kendala yang dihadapi selama kegiatan program ataupun responden membuat laporan kegiatan mingguan tentang kegiatannya yang kemudian setiap minggu akan dievaluasi. Tingkat partisipasi pada tahap monitoring program diukur dengan menjumlahkan skor dari hasil jawaban responden.

Partisipasi responden pada tahap monitoring program cukup rendah yaitu sebesar $51,11 \%$ atau sebanyak 23 orang. Hal ini disebabkan mereka merasa bahwa peran PLUT sudah baik sehingga mereka kurang aktif dalam mengevaluasi program pemberdayaan UMKM. Selain itu, mereka merasa proses evaluasi cukup dilakukan oleh penyelenggara pelatihan.

\section{Peningkatan Pendapatan}

Tingkat pendapatan dalam penelitian ini dilihat dari peningkatan pendapatan usaha responden sebelum dan sesudah adanya program pemberdayaan UMKM. Pengukuran dilakukan dengan menggunakan skala 1-10, kemudian dihitung selisih perubahannya. Tingkat pendapatan dibagi ke dalam tiga kategori yaitu rendah, sedang, tinggi.

Responden mengalami peningkatan pendapatan namun tidak begitu besar. Hal ini disebabkan Program Pemberdayaan UMKM tidak berpengaruh langsung terhadap peningkatan ekonomi masyarakat. Program ini hanya memberikan pelatihan-pelatihan untuk UMKM agar semakin mandiri dan tidak memberikan bantuan berupa modal usaha atau bantuan alatalat untuk produksi. Sedangkan menurut beberapa responden apabila ingin meningkatkan ekonomi mereka, pemerintah harus memberikan modal berupa uang.

Berdasarkan skala 1-10 yang digunakan dalam penelitian ini untuk mengukur tingkat pendapatan, sebagian besar responden hanya mengalami peningkatan pendapatan setinggi satu sampai dua tingkat. Responden mengalami peningkatan pendapatan setelah adanya Program Pemberdayaan UMKM karena menerapkan materi yang diberikan pada saat pelatihan ke dalam usaha mereka. Materi yang diberikan adalah umum dan dapat diterapkan di berbagai jenis UMKM.

Peningkatan pendapatan responden sebelum dan sesudah adanya program pemberdayaan UMKM tergolong sedang dengan jumlah 30 orang atau sebesar $66,67 \%$ dan rendah dengan jumlah 15 orang atau sebesar 33,33\%. Menurut hasil wawancara dengan salah satu responden, hal ini disebabkan karena dengan mengikuti pelatihan tidak berdampak langsung dengan peningkatan pendapatan mereka.

\section{Kemampuan Akses Pendidikan}

Akses terhadap pendidikan dalam penelitian ini dilihat dari kemampuan individu menyekolahkan 
anak dengan menggunakan pendapatan usaha mereka. Berbeda dengan tingkat pendidikan dalam karakteristik individu yang melihat jenjang terakhir sekolah yang ditamatkan oleh individu tersebut. Kemampuan akses pendidikan cenderung tinggi. Hal disebabkan adanya program BOS dan wajib belajar 9 tahun sehingga responden mampu menyekolahkan anak mereka dengan pendapatan dari hasil UMKM. Selain itu, tingkat kesadaran responden akan pentingnya pentingnya pendidikan juga cukup tinggi.

Kemampuan responden dalam mengakses pendidikan tergolong tinggi dengan jumlah 35 orang atau sebesar $77,78 \%$. Responden dengan kemampuan mengakses pendidikan berada pada tingkat sedang sebanyak delapan orang atau sebesar $17,78 \%$. Responden dengan kemampuan mengakses pendidikan sulit atau berada pada tingkat rendah sebanyak dua orang atau sebesar $4,44 \%$.

\section{Kemampuan Akses Kesehatan}

Motivasi seseorang dalam mengakses media bisa saja berbeda satu sama lain. Motivasi yang berbeda inilah yang memungkinkan tingkat penggunaan media masing-masing pengguna juga berbeda. Motivasi yang mendorong seseorang menggunakan media akan berpengaruh terhadap seberapa sering dan seberapa banyak waktu yang dialokasikan orang tersebut untuk mengakses media dalam rangka memenuhi motivasinya tersebut.

Mayoritas pengguna dengan tingkat motivasi sedang memiliki frekuensi penggunaan aplikasi Petani pada tingkat rendah, yaitu sebesar 93,3 persen, dan sisanya berada pada kategori frekuensi penggunaan sedang, yaitu sebesar 6,7 persen. Pengguna dengan tingkat motivasi tinggi memiliki frekuensi penggunaan yang lebih beragam, yaitu rendah sebesar 73,3 persen, sedang sebesar 20 persen, dan tinggi sebesar 6,7 persen. Hal ini menunjukkan bahwa motivasi untuk memperoleh informasi memiliki hubungan dengan frekuensi penggunaan aplikasi Petani. Keduanya berkorelasi dengan $p$ value 0.009 dan koefisien korelasi sebesar 0.470 , yang artinya keduanya memiliki hubungan yang positif dan sangat signifikan.
Akses terhadap pelayanan kesehatan dalam penelitian ini dilihat dari seberapa mudah individu memperoleh pelayanan kesehatan. Akses terhadap pelayanan kesehatan responden di Kabupaten Subang tergolong rendah atau sulit dengan jumlah 17 orang atau sebesar 37,78\%. Sedangkan sisanya dengan jumlah yang tidak jauh, tergolong sedang dan tinggi.

\section{Kondisi Perumahan}

Perumahan atau tempat tinggal rumah tangga adalah tempat berkumpulnya keluarga dan berfungsi sebagai tempat berlindung. Namun menurut BPS dalam Raya (2001), pada saat ini rumah tidak hanya berfungsi sebagai tempat berlindung tetapi sudah menjadi bagian dari gaya hidup, dan menunjukkan identitas pemiliknya. Kualitas rumah tinggal dan fasilitas yang digunakan dalam kehidupan sehari-hari mencerminkan tingkat kesejahteraan penghuninya.

Kondisi perumahan responden di Kabupaten Subang termasuk dalam kategori layak untuk dihuni karena kondisi rumah tempat tinggal keluarga mempunya atap, lantai, dan dinding dalam kondisi yang layak ditempati, baik dari segi perlindungan maupun dari segi kesehatan. Selain itu, ada juga fasilitas listrik dan air bersih serta fasilitas pendukung lainnya seperti asset rumah tangga misalnya televisi, kulkas, kipas angina dan lain-lain.

Hasil penelitian menunjukkan bahwa menunjukkan bahwa terdapat 41 perumahan atau sebesar $91,11 \%$ termasuk dalam kategori tinggi. Namun terdapat 4 perumahan atau sebesar $8,89 \%$ yang masih tergolong sedang dikarenakan rumah bukan milik sendiri (menumpang, sewa, kontrak) dan masih berlantai tanah dengan dinding setengah tembok.

\section{Hubungan Tingkat Umur dengan Tingkat Partisipasi}

Setelah dilakukan uji korelasi didapatkan hubungan antara tingkat umur dengan tingkat partisipasi. Hal ini dapat dilihat dari hasil nilai sig 2-tailed antara tingkat umur dengan tingkat partisipasi sebesar $-0,185$. Nilai tersebut termasuk ke dalam tidak adanya hubungan yang signifikan antara kedua variabel. 
Hasil ini berbeda dengan penelitian Manalu (2013), dimana tingkat umur berhubungan dengan partisipasi masyarakat dalam program bank sampah. Faktor umur berhubungan dengan keikutsertaan masyarakat dalam program bank sampah karena ketika usia seseorang masih mendukung untuk ikut berpartisipasi dalam suatu kegiatan, maka kemungkinan keikutsertaannya akan menjadi lebih besar. Umur seseorang memengaruhi pola bertindak dalam penyelesaian suatu masalah. Seiring bertambahnya usia, seseorang akan memerlukan penyesuaian diri untuk beraktifitas sehari-hari (Kusnoputranto, 2000).

Berdasarkan hasil penelitian, ditemukan sebanyak 12 responden atau sebesar 26,67\% responden memiliki tingkat umur rendah dan tingkat partisipasi tinggi. Hal ini disebabkan responden dengan tingkat umur rendah atau muda memiliki kemampuan fisik yang belum berkurang. Sebaliknya pada tingkat umur tinggi atau tua, kemampuan fisik seseorang mulai berkurang sehingga keadaan tersebut akan mempengaruhi partisipasi sosialnya.

Jumlah responden dengan tingkat partisipasi tinggi dari setiap tingkat umur sebanyak 23 orang atau sebesar 51,11\%. Berdasarkan pengamatan di lapangan, hal ini terjadi karena responden dengan memiliki semangat yang tinggi dalam berbisnis atau membuka usaha sehingga baik responden dengan tingkat umur rendah ataupun tinggi ikut berpartisipasi dalam program pemberdayaan UMKM.

\section{Hubungan Tingkat Pendidikan dengan Tingkat Partisipasi}

Hasil uji statistik yang diperoleh hubungan antara tingkat pendidikan dengan tingkat partisipasi adalah tidak terdapat hubungan. Hal ini dapat dilihat dari hasil nilai sig 2-tailed antara tingkat umur dengan tingkat partisipasi sebesar -0,150. Nilai tersebut termasuk ke dalam tidak adanya hubungan antara kedua variabel. Tingkat pendidikan tidak berhubungan dengan keikutsertaan responden dalam program pemberdayaan UMKM karena walaupun tingkat pendidikan tinggi tetapi responden juga harus mempunyai pengetahuan yang baik tentang berbisnis atau membuka usaha. Responden dengan berbagai tingkat pendidikan, dapat belajar kemampuan berbisnis sesuai dengan pengalaman hidupnya.

Berdasarkan hasil penelitian, ditemukan bahwa sebesar $17,78 \%$ responden memiliki tingkat pendidikan tinggi dan tingkat partisipasi rendah. Hal ini disebabkan karena responden merasa dengan latar belakang pendidikan yang dimiliki, responden tersebut mampu mengembangkan usahanya sendiri. Kemudian sebesar 44,44\% responden memiliki tingkat pendidikan tinggi dan tingkat partisipasi tinggi. Sebagian besar responden memahami pentingnya mengikuti Program Pemberdayaan UMKM sehingga mayoritas responden berada pada tingkat partisipasi tinggi.

Responden dengan tingkat pendidikan rendah dan tingkat partisipasi rendah hanya satu orang atau sebesar 2,22\%. Menurut responden, pengetahuan terkait usahanya bisa dipelajari sendiri dan berdasarkan pengalamannya. Hal ini juga terjadi pada responden dengan responden baik tingkat pendidikan rendah, sedang, tinggi dengan tingkat pasrtisipasi yang rendah.

\section{Hubungan Tingkat Pendapatan dengan Tingkat Partisipasi}

Hasil uji statistik yang diperoleh hubungan antara tingkat pendapatan dengan tingkat partisipasi adalah tidak terdapat hubungan. Hal ini dapat dilihat dari hasil nilai sig 2-tailed antara tingkat umur dengan tingkat partisipasi sebesar $-0,083$. Nilai tersebut termasuk ke dalam tidak adanya hubungan antara kedua variabel.

Berdasarkan hasil penelitian, ditemukan bahwa mayoritas responden berada pada tingkat pendapatan rendah dan tingkat partisipasi tinggi yaitu sebanyak 15 orang atau sebesar 33,33\%. Hasil ini sesuai dengan pengamatan di lapang, responden dengan tingkat pendapatan rendah akan lebih termotivasi untuk mengikuti pelatihanpelatihan dalam program pemberdayaan UMKM. Responden menganggap dengan mengikuti pelatihan-pelatihan ini akan mampu meningkatkan nilai jual produk mereka sehingga pendapatan mereka pun juga akan meningkat. 
Responden dengan tingkat pendapatan tinggi hanya tiga orang dengan partisipasi cukup tinggi. Responden tetap berpasrtisipasi dalam program karena membuka usaha merupakan pekerjaan utama mereka sehingga mereka tidak ada kegiatan lain dan memilih mengikuti pelatihan dalam program pemberdayaan UMKM. Selain itu, responden juga ingin menambah teman atau relasi dengan mengikuti pelatihan tersebut.

\section{Hubungan Tingkat Partisipasi Reponden dalam Program Pemberdayaan UMKM dengan Tingkat Kesejahteraan Peserta}

Berdasarkan data penelitian, maka mayoritas responden dengan tingkat partisipasi tinggi memiliki tingkat kesejahteraan yang tinggi pula. Responden dengan tingkat partisipasi dan tingkat kesejahteraan tinggi sebanyak 18 orang atau sebesar $40 \%$. Melihat dari kenyataan di lapangan, hal ini disebabkan responden yang aktif berpartisipasi senantiasa menerapkan materimateri yang diberikan saat pelatihan. Selain itu, mempunyai usaha yang berhasil merupakan salah satu dari impian mereka sehingga mereka selalu berusaha dengan baik termasuk mengikuti program pemberdayaan UMKM. Dengan adanya program ini, perlahan-lahan mereka mampu meraih apa yang diimpikan selama ini.

Selain untuk meningkatkan kesejahtaraan dirinya dan keluarganya, beberapa responden juga berniat untuk menyejahterakan masyarakat di lingkungan tempat tinggalnya. Salah satu cara agar masyarakat sekitar ikut merasakan manfaat dari pelatihan adalah responden mengajak masyarakat sekitar tempat tinggal mereka untuk menjadi karyawan. Kemudian, beberapa responden juga membuat kelompok-kelompok kecil untuk membuat usaha kecil, seperti kerajinan tangan dan makanan. Mereka mempraktekkan materi dari PLUT dan mengajarkan kepada kelompok-kelompok kecil tersebut. Berdasarkan hasil pengamatan di lapangan, daerah yang sudah menerapkan hal ini ada di Desa Cibeusi, Ciater dan di Desa Sukamelang.

Responden dengan tingkat partisipasi rendah dan tingkat kesejahteraan sedang sebanyak satu orang atau sebesar 2,22\%. Responden dengan tingkat partisipasi sedang dan tingkat kesejahteraan sedang sebanyak dua orang atau sebesar 4,44\%. Responden dengan tingkat pasrtisipasi sedang dan tingkat kesejahteraan tinggi sebanyak 10 orang atau sebesar $22,22 \%$. Responden dengan tingkat pasrtisipasi rendah dan tingkat kesejahteraan tinggi sebanyak Sembilan orang atau $20 \%$.

Responden dengan tingkat partisipasi rendah namun tingkat kesejahteraan tinggi terjadi karena mereka sudah mempunyai ilmu-ilmu pengetahuan mengenai usaha yang mereka jalankan tanpa harus mengikuti pelatihan. Selain itu responden juga memiliki jaringan yang luas dan mampu mengoperasikan internet dengan baik sehingga usaha mereka berkembang dengan baik. Hal ini juga disebabkan karena anggota keluarga responden memilki jenis pekerjaan yang lain.

Berdasarkan kondisi di lapangan, tidak adanya hubungan antara tingkat partisipasi responden dalam program pemberdayaan UMKM dengan tingkat kesejahteraan resonden disebabkan oleh tidak adanya partisipasi pada tahap perencanaan. Perencanaan program pemberdayaan UMKM langsung dari pemerintah atau dinas koperasi. Hal ini mengakibatkan pelatihan-pelatihan yang terdapat pada program pemberdayaan UMKM kurang tepat dan efektif. Materi pelatihan yang diberikan kurang sesuai dengan kebutuhan responden. Sehingga menimbulkan kejadian seperti tingkat pastisipasi tinggi namun tidak meningkatkan pendapatan mereka dalam berusaha.

\section{SIMPULAN DAN SARAN}

\section{Simpulan}

Berdasarkan pada permasalahan dan pembahasan pada bab-bab sebelumnya, serta hasil studi dan analisis yang telah dilakukan, maka dapat ditarik kesimpulan sebagai berikut:

1. Tidak terdapat hubungan antara karakteristik individu (tingkat umur, tingkat pendidikan, tingkat pendapatan) dengan tingkat partisipasi peserta dalam program pemberdayaan UMKM.

2. Tidak terdapat hubungan antara tingkat partisipasi peserta program pemberdayaan UMKM dengan tingkat kesejahteraan peserta. 


\section{Saran}

Berdasarkan hasil penelitian, beberapa hal yang dapat dijadikan sebagai saran antara lain:

1. Bagi Dinas Koperasi dan UMKM, sebaiknya melibatkan masyarakat atau peserta program dalam tahap perencanaan pembuatan suatu program. Agar pelatihan-pelatihan atau materi yang diberikan sesuai dengan kebutuhan masyarakat sehingga program dapat berjalan lebih efektif dan efiseien.

2. Bagi masyarakat, sebaiknya turut berpartisipasi dalam program pemberdayaan. Bukan hanya dalam tahap pelaksanaan saja, namun tahap lainnya seperti tahap perencanaan, menikmati hasil, dan evaluasi.

\section{DAFTAR PUSTAKA}

[BPS] Badan Pusat Statistik. 2000. Indikator Sosial Ekonomi Indonesia.

[BPS] Badan Pusat Statistik. 2015. Indikator Kesejahteraan Rakyat di Indonesia.

[BPS] Badan Pusat Statistik. 2016. Perkembangan UMKM Periode 1997-2013.

[UU] Undang-Undang Nomor 20 Tahun 2008 tentang Usaha Mikro, Kecil, dan Menengah

[UU] Undang-Undang Nomor 11 Tahun 2009 tentang Kesejahteraan Sosial.

Ainiya R. 2014. Tingkat Partisipasi dan Efektivitas Lembaga Keuangan MIkro (LKM) Posdaya Sauyunan [skripsi]. Bogor (ID): Institut Pertanian Bogor.

Ajiswarman.1996. Partisipasi Perantau Minang dalam Pembangunan Pedesaan (Studi Kasus: Kelompok Tani Subur Jaya, Desa Ciherang, Kecamatan Dramaga, Kabupaen Bogor, Jawa Barat) [skripsi]. Bogor (ID): Institut Pertanian Bogor.

Arifini NK, Mustika MD. 2013.Analisis Pendapatan Pengrajin Perak di Desa Kamasan Kabupaten Klungkung. [Internet]. [diunduh 2016 September 23]. http://ojs.unud.ac.id/index.php/eep/article/vie $\mathrm{w} / 5449 / 4306$

Arnstein, SR. 1969. A Ladder of Citizen Participation. Journal of the American Planning Assiciation, Volume 35 (4).

Avianti A, Sihaloho M. 2013. Peranan Pekerja Anak di Industri Kecil Sandal terhadap Pendapatan Rumahtangga dan Kesejahteraan Dirinya di Desa Parakan, Kecamatan Ciomas, Kabupaten Bogor, Jawa Barat. [Internet]. [diunduh 2016
Oktober

12].

http://journal.ipb.ac.id/index.php/sodality/artic le/view/9386

Berampu AC. 2014. Manfaat Partisipasi Masyarakat Dalam Program Bank Sampah Binaan CSR PT PLN Persero [skripsi]. Bogor (ID): Institut Pertanian Bogor.

Candora. 2013.Analisis Faktor-Faktor yang Mempengaruhi Pendapatan Pengrajin Batik Kayu. [Internet]. [diunduh 2016 September 23]. http://e-journal.uajy.ac.id/id/eprint/4850

Dewi PM. 2012. Partisipasi Tenaga Kerja Perempuan dalam Meningkatkan Pendapatan Keluarga. [Internet]. [diunduh 2016 September 23]. http://download.portalgaruda.org/article.php?a rticle $=14223 \&$ val $=953$

Erawati RV, Kirwani. 2014. Kontribusi Industri Kerajinan Kulit Bagi Pendapatan Tenaga Kerja di Kabupaten Magetan. [Internet]. [diunduh 2016 September 23]. ejournal.unesa.ac.id/index.php/jupe/article/vie w/924

Fatmawati F, Setiyono I. 2013. Perbedaan Pendapatan Masyarakat Sebelum dan Sesudah Adanya Industri Kecil Rambak di Desa Kauman Kecamatan Bangsal Kabupaten Mojokerto. [Internet]. [diunduh 2016 Desember 8]. ejournal.unesa.ac.id/index.php/jupe/article/vie $\mathrm{w} / 3596$

Friedman J. 1992. Empowerment. The politics of an alternative development. Oxford: Basil Blackwell. xii+196 pp. ISBN: 1557863008.

Ghofur A. 2014. Pengaruh Adanya Industri Kerajinan Songkok terhadap Tingkat Pendapatan Masyarakat. [Internet]. [diunduh 2016 September 23 ]. http://journal.unisla.ac.id/pdf/12922013/3.pdf

Huzein F.2013. Analisis Efektivitas Program Pemberdayaan Masyarakat (Studi Kasus: Persepsi Masyarakat Miskin Terhadap Program Nasional Pemberdayaan Masyarakat Mandiri Pedesaan di Kecamatan Tegalampel Kabupaten Bondowoso) [skripsi]. Jember (ID): Universitas Jember.

Krisdayanti F. 2016. Peran Pendamping dan Partisipasi Peserta dalam Program Simpan Pinjam Khusus Perempuan [skripsi]. Bogor (ID): Institut Pertanian Bogor.

Kusnoputranto H. 2000. Kesehatan Lingkungan. Jakarta (ID): Universitas Indonesia.

Manalu SP. 2013. Faktor-Faktor yang Berhubungan dengan Partisipasi Masyarakat dalam Program Bank Sampah di Kelurahan Binjai Kecamat

an Medan Denai Kota Medan Tahun 2013 [jurnal]. Vol.3 No.1 Universitas Sumatera Utara. 
Mosher. 1987. Menggerakkan Dan Membangun Pertanian. Jakarta: Yasaguna.

Murray R and Lappin BW. 1967. Community Organization: Theory, Principles and Practice, $2^{\text {nd }}$ Ends. New York: Harper and Row Publisher.

Nasdian FT. 2006. Pengambangan Masyarakat (Community Development). Bogor (ID): Institut Pertanian Bogor.

Pangestu MHT. 1995. Partisipasi Masyarakat dalam Pelaksanaan Kegiatan Perhutanan Sosial (Studi Kasus: KPH Cianjur, Jawa Barat). [Tesis]. Bogor (ID): Pascasarjana IPB.

Pinatik M. 2014. Partisipasi masyarakat dalam Pelaksanaan program pembangunan di Kecamatan Talawaan Kabupaten Minahasa Utara. Jurnal Eksekutif [internet]. [diunduh pada 21 Februari 2017]. Dapat diunduh dari http://ejournal.unsrat.ac.id/index.php/jurnaleks ekutif/article/view/4711/4235.

Pranaka AMW, Moejato. 1996. Pemberdayaan Konsep, Kebijakan dan Implementasi. Jakarta (ID): CSIS.

Rifa'i B. 2013. Efektivitas Pemberdayaan Usaha Mikro Kecil dan Menengah (UMKM) Krupuk Ikan dalam Program Pengembangan Labsite Pemberdayaan Masyarakat Desa Kedung Rejo Kecamatan Jabon Kabupaten Sidoarjo. Kebijakan dan Manajemen Publik [internet]. [diunduh pada 06 Februari 2017]; (01): 130136. Dapat diunduh dari http://journal.unair.ac.id/filerPDF/16\%20Bakti ar_KMP\%20V1\%20N1\%20JanApril\%202013.pdf

Raya R. 2001. Pengelompokan Propinsi berdasarkan Perubahan Tingkat Kesejahteraan Rakyat [tesis]. Bogor (ID): Institut Pertanian Bogor. 55 hal.

Rosalina I. 2014. Efektivitas Program Nasional Pemberdayaan Masyarakat Mandiri Perkotaan Pada Kelompok Pinjaman Bergulir di Desa Mantren kecamatan Karangrejo Kabupaten Magetan. E-Journal UNESA [internet]. [diunduh pada 06 Februari 2017]; (01): 0-216. Dapat diunduh dari http://ejournal.unesa.ac.id/index.php/publika/a rticle/view/7675.

Sajogyo. 1998. Menuju Kemandirian Masyarakat. Prisma No.1 Tahun XVII. Jakarta (ID): PT Pustaka LP3ES Indonesia.

Setiawan B. 2010. Strategi Pengembangan Usaha Kerajinan Bambu di Wilayah Kampung Pajeleran Sukahati Kecamatan Cibinong Kabupaten Bogor. [Internet]. [diunduh 2016 September http://www.manajemen.fem.ipb.ac.id/images/u ploads/6._Strategi_Pengembangan_Usaha_Ke rajinan.pdf

Singarimbun M dan Effendi S. 2012. Metode Penelitian Survai. Jakarta (ID): LP3ES

Singka FN. 2014. Analisis Kondisi Usaha dan Strategi Pengembangan Industri Kecil Berbasis Komunitas Lokal [tesis]. Bogor (ID): Institut Pertanian Bogor.

Suarmawan KA. 2015. Analisis Faktor-Faktor yang Mempengaruhi Keberhasilan Usaha Mikro dan Kecil (Studi pada Usaha Kerajinan Ingka di Desa Bulian, Kec. Kubutambahan). [Internet]. [diunduh 2016 November 23]. http://ejournal.uajy.ac.id/id/eprint/4850

Sudirja R. 2007. Partisipasi Perempuan dalam Penyusunan Program Pembangunan Pertanian di Pedesaan. Bandung (ID): Fakultas Pertanian Universitas Padjajaran

Suhendra K. 2006. Peranan Birokrasi dalam Pemberdayaan Masyarakat. Bandung (ID): Alfabeta.

Sulistiyani AT. 2004. Kemitraan dan Model-Model Pemberdayaan. Yogyakarta (ID): Gava Media.

Syarif A, Harini R. 2012. Industri Genteng di Desa Sidoluhur Kecamatan Godean Kabupaten Sleman. [Internet]. [diunduh 2016 September 23].

http://lib.geo.ugm.ac.id/ojs/index.php/jbi/articl e/view/36

Tamarli. 1994. Partisipasi Petani dalam Penyuluhan Desa dan Penerapan Program Supra Insus [tesis]. Bogor (ID): IPB Press

Tambunan TH. 2009. UMKM di Indonesia. Bogor (ID): Ghalia Indonesia

Tilaar HAR. 2009. Kekuasaan dan Pendidikan: Manajemen Pendidikan Nasional dalam Pusaran Kekuasaan. Jakarta: Rineka Cipta

Uphoff NT, Cohen JM, dan Goldsmith AA. Rural Development Committee: Feasibility and Application of Rural Development Participation: A. State-of-the-Arth Paper. New York: Cornell University

Yunita A. 2015. Hubungan Partisipasi dengan Pelaksanaan Kegiatan dan Kesejahteraan Anggota Pinjaman Dana Bergulir di Desa Terusan, Kabupaten Indramayu [skripsi]. Bogor (ID): Institut Pertanian Bogor. 